\title{
Occupational health risk of working in garages: comparative study on blood pressure and hematological parameters between garage workers and Haramaya University community, Harar, eastern Ethiopia
}

This article was published in the following Dove Press journal:

Risk Management and Healthcare Policy

\section{Zerihun Ataro' \\ Abraham Geremew ${ }^{2}$ \\ Fekadu Urgessa ${ }^{3}$ \\ 'Department of Medical Laboratory Sciences, ${ }^{2}$ Department of \\ Environmental Health Sciences, \\ College of Health and Medical \\ Sciences, Haramaya University, Harar, Ethiopia, ${ }^{3}$ School of Medical Laboratory Science, College of Health Sciences, Addis Ababa University, Addis Ababa, Ethiopia}

Background: Occupational exposure to chemicals in garages causes a wide range of biological effects, depending upon the level and duration of exposure. In Ethiopia, there have been few studies conducted to assess the exposure of garage workers to chemicals. Preceding studies have not explored the effect of working in garage on blood pressure and hematological parameters. Therefore, this study aimed to assess differences in blood pressure and hematological parameters among garage workers compared to the Haramaya University community, Harar, eastern Ethiopia. Materials and methods: A comparative cross-sectional study was conducted in Harar town, eastern Ethiopia. Thirty garage workers were selected and compared with 30 age- and sexmatched controls comprising of teachers and students. Demographic and occupational data were collected by using a structured questionnaire by a trained data collector. Blood pressure was measured using sphygmomanometry. Hematological parameters were measured with an automated hematology analyzer. Data were analyzed using Stata version 13.

Results: The majority of the garage workers did not implement effective preventive or control measures for workplace chemical exposure. Statistically significant increases were found in systolic $(128.67 \pm 18.14$ vs $106.33 \pm 9.27 \mathrm{mmHg}, P<0.0001)$, diastolic blood pressure $(90.33 \pm 11.29$ vs $75.67 \pm 5.68 \mathrm{mmHg}, P<0.0001)$, total white blood cells $\left(7.9 \pm 1.51\right.$ vs $6.72 \pm 2.04 \times 10^{9}$ cells $/ \mathrm{L}$, $P=0.0138)$, and platelets $\left(323.20 \pm 48.82\right.$ vs $244.1 \pm 47.3 \times 10^{9}$ cells $\left./ \mathrm{L}, P<0.0001\right)$ in garage workers compared to the control group. On the other hand, statistically significant decreases were found in red blood cells $\left(5.13 \pm 0.38\right.$ vs $5.46 \pm 0.36 \times 10^{12}$ cells $\left./ \mathrm{L}, P=0.0006\right)$, hemoglobin $(14.89 \pm 0.71$ vs $15.45 \pm 0.87 \mathrm{~g} / \mathrm{dL}, P=0.0062)$, hematocrit $(43.98 \% \pm 1.99 \%$ vs $46.4 \% 3 \pm 2.32 \%, P<0.0001)$, and mean corpuscular volume $(83.19 \pm 2.93$ vs $85.11 \pm 3.87 \mathrm{fL}, P=0.0353)$ among garage workers compared to the control group.

Conclusion: There were significant differences in blood pressure and hematological parameters between garage workers and the control group. Therefore, appropriate and effective safety measures need to be taken by the workers to prevent possible chemical exposure during routine tasks. Keywords: garage workers, blood pressure, hematological parameters, Harar, Ethiopia

\section{Introduction}

Automobile garages are a small-scale industry composed of skilled workers, such as mechanics, spray-painters, panel beaters, welders, battery recyclers, and radiator and air-conditioner repairers. They are situated along roadsides and in interiors of

Fax +25I 2525666808

Email zerihunataro@yahoo.com 
informal settlements to service motor vehicles that break down on the roads. These workshops have been identified as major sources of environmental pollution, because of the unregulated practices of these workers. ${ }^{1}$

A distinctive feature of garages is that workers deal with dirt as part of their routine work. Because of the interaction between garage workers and the cars that they service, repair, and maintain, garage work is considered "dirty". Unlike the modern clean factory in which new car parts are being assembled, the workers in garages get dirty as they work and different substances contaminate the environment continually. ${ }^{2}$ A study explored the overall health hazards of automobile-repair-shop wastewater on workers who randomly handled toxic wastewater during battery, car, and oil/grease washing. The water is polluted by lead and cadmium, and in the course of their work they are exposed to these exogenous elements, which puts them in a susceptible position. ${ }^{3}$ Workplace safety is undermined by poor working environments, ie, dirty workplaces. Poor workplace organization has been found across all sectors, with associated tripping hazards. ${ }^{4}$

Garage workers are exposed to a wide range of chemicals, including heavy metals, contained in brake fluids, degreasers, detergents, lubricants, metal cleaners, benzene, solvents, and asbestos (from brake repair), as well as welding fumes and car exhausts. ${ }^{5,6}$ A study showed significantly increased levels of lead, cadmium, chromium, zinc, and copper in mechanics, spray-painters and battery recyclers compared with unexposed controls. ${ }^{1,3,7,8}$

Biological monitoring of chemical exposure in the workplace has become increasingly important in the assessment of health risk as an integral part of the overall occupational health and safety strategy. Biological monitoring is an important tool in the prevention of occupational diseases related to those exposed to chemicals on a regular basis. In order to evaluate workplace conditions on a continuous basis, emphasis should be placed on environmental monitoring, complemented by biological monitoring. ${ }^{9}$

The major ultimate objective of an occupational-exposure assessment is to evaluate health risk for the exposed population and to implement control measures if the risk is considered unacceptable. Biological monitoring of chemical exposure is the evaluation of the internal dose (internal exposure) by a biological method with the view of assessing the associated health risk. ${ }^{10}$ Estimation of the internal dose has usually relied on two categories of tests: those based on the determination of the chemical and/or its metabolites in various biological media, and those based on the quantification of a nonadverse biological effect, the intensity of which is related to the internal dose. Biomarkers are generally classified into three categories: biomarkers of exposure, biomarkers of early biological effects, and biomarkers of susceptibility. ${ }^{11,12}$

A brief history of biological monitoring and reference values of biomarkers for occupational-exposure chemicals has been established by different professional organizations. ${ }^{9}$ The American Conference of Governmental Industrial Hygienists $^{13}$ and German Research Foundation ${ }^{14}$ publish annual lists of biological monitoring guidelines for those substances. Biological-exposure indices are reference values intended as guidelines for the evaluation of potential health hazards in the practice of occupational hygiene. ${ }^{10}$

Activities in small-scale industries are occupationally risky, due to lack of regulation, supervision, and application of standards by concerned authorities. ${ }^{4}$ In low-income countries, the number of temporary and unauthorized garages is high, and most workers are illiterate and work without any safety measures. ${ }^{3}$ Most of them are involved in jobs that expose them to gradual health risks from exposure to a wide range of chemicals without having any idea about the materials they are handling. ${ }^{15,16}$

Many chemicals to which garage workers are occupationally exposed have toxicity in hematopoietic organs. Various researchers have identified different types of effects on workers, and these include hematological disorders and increased blood pressure. ${ }^{6,17}$ Assessment of benzene exposure extent in different South Korean industries showed a high risk of hematopoietic disorders. ${ }^{18}$ Decreased erythrocyte, hemoglobin, hematocrit, and platelet levels have been reported among car mechanics in Zagazig, Egypt. ${ }^{6}$ Aromatic solvent exposure results in decreased mean red blood cell (RBC) and hemoglobin values among automobile-repair workers. ${ }^{19}$ On the other hand, exposure to lead, benzene, and mixtures of organic solvents results in increased systolic and diastolic blood pressures. ${ }^{20,21}$ These results show that chemical exposure in garage workers affects the health of the workers.

In developing countries, exposure to hazardous chemicals is common. A study conducted in Nigeria indicated increased exposure to premium motor-spirit fumes among automobile mechanics and petrol-station attendants. Mean packed-cell volume was lower in automobile mechanics (33.3\%) than subjects from the general population $(40.8 \%))^{22}$ It was also indicated that hazardous stationary emissions of petroleum air and soil pollutants in automobile workshops led to higher risk of hematological dysfunctions. ${ }^{23}$ A study from Iran indicated that exposure to mixtures of organic solvents may be associated with the prevalence of hypertension in carmanufacturing workers. ${ }^{21}$ 
In Ethiopia, there are indications that garage workers in small-scale garages are exposed to lead. ${ }^{7,24}$ Studies have shown high blood lead levels in exposed garage workers compared to controls. Although there are many small- and large-scale industries that may pose health risks to workers in the country, there are no workplace regulations for chemical exposure. No data are available from labor departments on workers of small-scale units and chemical poisoning. ${ }^{24}$

Further, to the best of the investigators' knowledge, the laboratory profile of garage workers as a result of their occupational exposure has not been investigated. Therefore, this study was carried out to describe blood pressure and hematological parameters and to determine their differences among garage workers compared to the Haramaya University community in Harar, Ethiopia.

\section{Materials and methods Study design}

A comparative cross-sectional study was carried out among garage workers between May and August, 2016 in Harar, eastern Ethiopia.

\section{Subjects}

Study subjects comprised 30 occupationally exposed garage workers and 30 occupationally unexposed university students and teachers at the College of Health and Medical Sciences, Haramaya University as a control group.

\section{Inclusion and exclusion criteria}

Garage workers directly involved in automobile-repair works and working in the garage for at least 1 year were included. Garage workers with a previous history of hypertension or known chronic illnesses, such as diabetes mellitus and cardiovascular diseases, were excluded from the study. The unexposed (control) group comprised apparently healthy individuals matching the exposed group in age and sex.

\section{Sample size}

Sample size was calculated based on a formula for comparison of two sample means. From a study carried out in Pakistan among garage workers, we got mean hemoglobin levels of $14.7 \pm 0.6 \mathrm{~g} / \mathrm{dL}$ in garage workers and $15.21 \pm 0.7 \mathrm{~g} / \mathrm{dL}$ in the control group. ${ }^{19}$ We used Stata software to estimate sample size with specified significance level $(0.05)$, power $(80 \%)$, and proportion of 1:1 for cases and controls. From this, we got $n_{1}=26$ and $n_{2}=26$. By including a $15 \%$ nonresponse rate, we get $n_{1}=30$ and $n_{2}=30$. Therefore, our study subjects comprised 30 occupationally exposed garage workers and 30 occupationally unexposed controls.

\section{Sampling \\ Selection of garage workers}

A preliminary assessment was conducted to establish the number of garages and number of workers in Harar. We found that there were a total of 112 garage workers working in 28 garages. Of these 112 workers, 98 fulfilled the inclusion criteria and were used as the sample frame. Thirty garage workers that fulfilled the inclusion criteria were selected randomly. The randomization process took place by assigning a number for each garage worker and selecting them by a table of random numbers.

\section{Selection of control group}

Controls were selected from students and teachers at the College of Health and Medical Sciences, Haramaya University. Lists of students and teachers were obtained from the departments/schools of the college. From these lists, those individuals that fulfilled the inclusion criteria for controls were identified. The College of Health and Medical Sciences contains five schools and two departments consisting of a total of 154 teachers. For the purpose of selecting students, the Department of Medical Laboratory Sciences was selected randomly by lottery. There are 98 students in this department. The sampling frame for the control group consisted of 154 teachers and 98 students. Then, each of the students and teachers in the sampling frame was assigned a unique number and 30 selected randomly using a table of random numbers.

\section{Data collection}

After obtaining consent from study subjects, demographic and occupational data were collected using a structured questionnaire, and subjects were interviewed by trained data collector (nurse). The questionnaire included age, sex, marital status, work duration, use of personal protective equipment, alcohol-consumption, smoking, khat chewing and eating habits, and taking showers at the workplace.

Prior to blood collection, resting blood pressure was measured by nurses using sphygmomanometry. Blood samples were collected from workers during their routine working hours. About $4 \mathrm{~mL}$ blood samples were collected using venipuncture techniques into a Vacutainer tube containing potassium EDTA-K3 from the antecubital area of study participants. All specimens were labeled and checked to ensure that stoppers were securely closed. The tubes were 
then placed in a holder or rack and placed/stored undisturbed in a container (cold box) at an appropriate temperature $\left(4^{\circ} \mathrm{C}-8^{\circ} \mathrm{C}\right)$. Then, specimens were transported to the laboratory using the cold box. For collection and transport of blood specimens, standard guidelines from the National Committee for Clinical Laboratory Standards (now the Clinical and Laboratory Standards Institute) were used. ${ }^{25}$ All samples were analyzed as quickly as possible (within 4 hours of blood collection). Analyses of hematological parameters were performed using an automated hematology analyzer (KX-21N; Sysmex, Kobe, Japan).

\section{Data processing and analysis}

All the data were cleaned, double-entered into Microsoft Excel spreadsheets and analyzed using Stata software version 13 (StataCorp, College Station, TX, USA). Descriptive summaries were presented in terms of means, SD, and proportions depending on the scale of the variable. Unpaired Student's $t$-tests were used to test the statistical significance of differences in selected parameters between the garage workers and the control group. Multiple linear regression analysis was used to test the association between each of the dependent variables (hematological parameters and blood pressure) and behavioral characteristics, with job-related parameters as independent variables. Medical outcomes were the dependent variable and age, working duration, smoking at the workplace $(0=$ no, $1=$ yes $)$, drinking at workplace $(0=$ no, $1=$ yes $)$, chewing khat at work place $(0=$ no, $1=$ yes $)$, personal protective equipment use $(0=$ user, $1=$ nonuser $)$, and taking showers at the workplace $(0=$ no, $1=$ yes $)$ as the independent variables.

For each outcome variable, simple linear regression was done using each independent variable. Then, we selected those variables with $P>0.2$ and ran multiple regression for each outcome variables. Multiple linear regression analyses were applied to determine whether there were increases or decreases in hematological measures with increasing exposure. All assumptions for linear and multiple regressions were checked. Diagnostics for multicollinearity among the independent variables were done on all equations using the variance inflation factor. Those independent variables with variance inflation-factor values $>10$ were taken as indicative of multicollinearity and removed from the multiple linear regressions. $P<0.05$ was considered statistically significant.

\section{Ethical considerations}

The study proposal was approved by the Institutional Research and Ethics Review Committee of College of Health and Medical Sciences, Haramaya University. All participants gave informed written consent to take part in this study. Only those individuals willing to participate were recruited. They were informed clearly about the purpose of investigations and expected outcomes. The results of the laboratory tests were given to the study participants.

\section{Results \\ General characteristics}

Personal characteristics of the garage workers and control group are presented in Table 1. They were comparable with regard to age and sex. All of the garage workers were males. The age of the workers was $18-53$ years, with mean \pm SD of $30.4 \pm 8.2$. Most of the workers $(20[66.67 \%])$ were found to have worked in their garage for $\leq 7$ years. Protective measures were poorly followed during work in garages. The majority of the workers $(24[80 \%])$ did not use any kind of personal protective equipment. Eleven (36.67\%), 19 (63.33\%), 13 (43.33\%), $22(73.33 \%)$, and $14(46.67 \%)$ workers had a habit of smoking, drinking, eating, chewing khat, and taking showers at work, respectively. We observed that all the garage workplaces were dusty and the workers did not follow safety measures (Figure 1).

Regarding possible routes of chemical entry into the body, $16(53.3 \%)$ workers mentioned that inhalation was the route of entry, followed by $15(50 \%)$ who reported that ingestion was the route, and 13 (43.3\%) who claimed that skin was the route of entry. A total of 12 (40\%) workers had knowledge about the effects of chemicals on human health. Workers had neither attended training courses nor had health professionals visit their station.

\section{Blood pressure and hematological parameters}

Mean systolic blood pressure (128.67 \pm 18.14 vs 106.33 $\pm 9.27 \mathrm{mmHg}, P<0.0001)$ and diastolic blood pressure $(90.33 \pm 11.29$ vs $75.67 \pm 5.68 \mathrm{mmHg}, P<0.0001)$ were significantly increased in garage workers compared to the control group (Table 2). Statistical analysis showed that significant decreases in RBCs, hemoglobin, hematocrit, and mean corpuscular volume (MCV) were observed among garage workers compared to the control group. In contrast, total white $\mathrm{BC}$ (WBC) count and platelet values were found to be higher in garage workers than controls. There were no significant differences in mean corpuscular hemoglobin $(\mathrm{MCH})$ or $\mathrm{MCH}$ concentration $(\mathrm{MCHC})$ between the two groups (Table 3). 
Table I Personal characteristics of garage workers and controls in Harar

\begin{tabular}{|c|c|c|c|}
\hline Characteristics & & $\begin{array}{l}\text { Garage workers }(n=30) \text {, } \\
n(\%)\end{array}$ & $\begin{array}{l}\text { Control group }(n=30) \text {, } \\
n(\%)\end{array}$ \\
\hline Age (years) & Mean (range) & $30.36(18-53)$ & $29.66(19-49)$ \\
\hline \multirow[t]{3}{*}{ Age-group (years) } & $18-27$ & $12(40)$ & $12(40)$ \\
\hline & $28-37$ & $13(43.33)$ & $13(43.33)$ \\
\hline & $38-53$ & $5(16.67)$ & $5(16.67)$ \\
\hline \multirow[t]{2}{*}{ Sex } & Male & 30 & 30 \\
\hline & Female & - & - \\
\hline \multirow[t]{4}{*}{ Educational status } & Write and read only & $4(13.33)$ & - \\
\hline & Primary & $8(26.67)$ & - \\
\hline & Secondary & $17(56.67)$ & - \\
\hline & Tertiary & I (3.33) & $30(100)$ \\
\hline \multirow[t]{2}{*}{ Khat chewing } & Yes & $8(26.67)$ & $5(16.67)$ \\
\hline & No & $22(73.33)$ & $25(83.33)$ \\
\hline \multirow[t]{2}{*}{ Smoking status } & Yes & II (36.67) & 0 \\
\hline & No & $19(63.33)$ & $30(100)$ \\
\hline \multirow[t]{2}{*}{ Work duration (years) } & $\leq 7$ & $20(66.67)$ & - \\
\hline & $>7$ & $10(33.33)$ & - \\
\hline \multirow[t]{2}{*}{ PPE use during work } & Yes & $6(20)$ & - \\
\hline & No & $24(80)$ & - \\
\hline \multirow[t]{2}{*}{ Drinking at workplace } & Yes & $19(63.33)$ & - \\
\hline & No & II (36.67) & - \\
\hline \multirow[t]{2}{*}{ Eating at workplace } & Yes & $13(43.33)$ & - \\
\hline & No & $17(56.67)$ & - \\
\hline \multirow[t]{2}{*}{ Showering at workplace } & Yes & $14(46.67)$ & - \\
\hline & No & $16(53.33)$ & - \\
\hline
\end{tabular}

Abbreviation: PPE, personal-protection equipment.

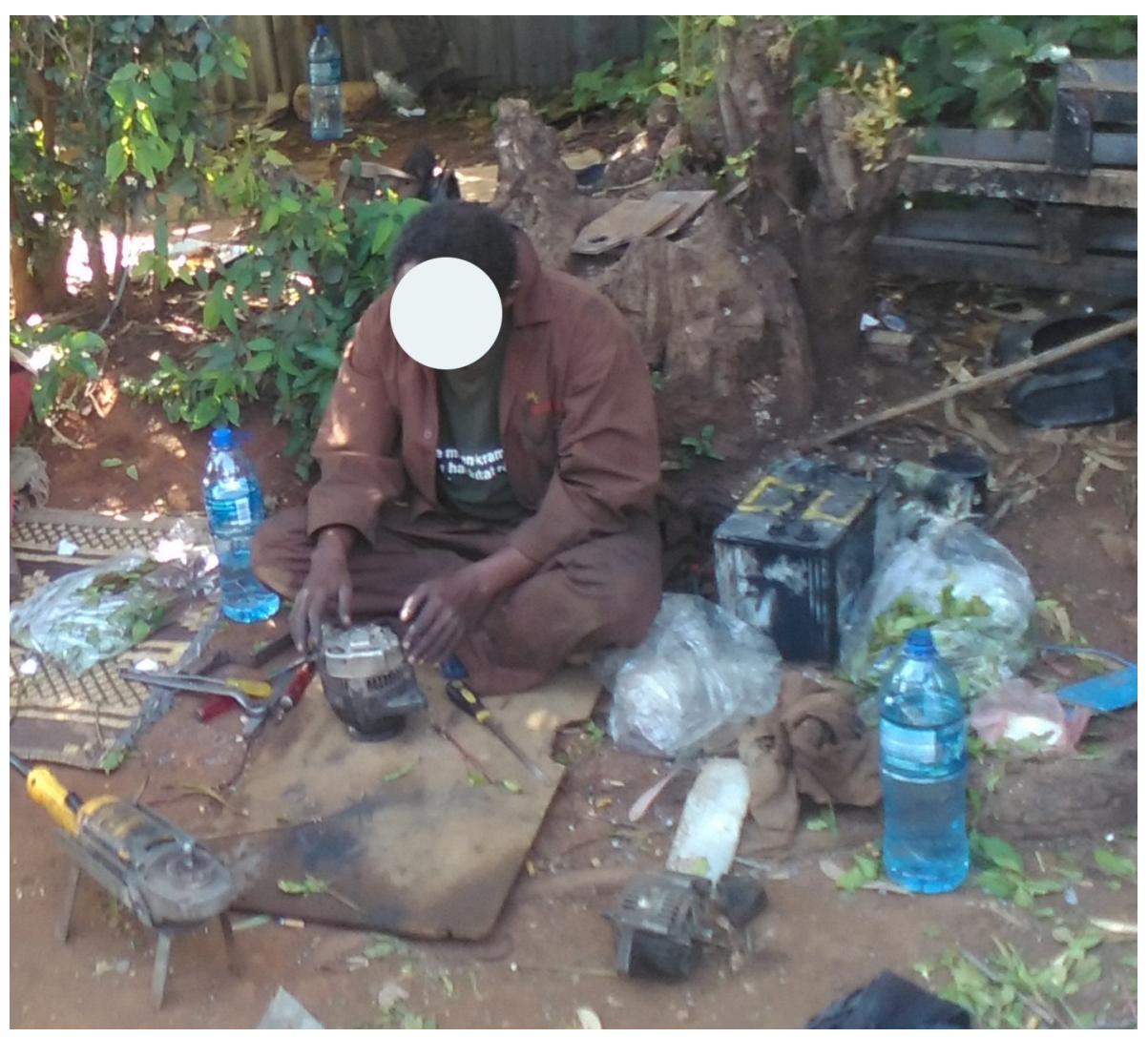

Figure I Partial view of working practice in one of the garages.

Note: Workers are engaged in routine activities without proper personal protective equipment, in a dusty place, and have a habit of chewing khat and drinking water during work. 
Table 2 Systolic and diastolic blood pressures of garage workers and control group in Harar

\begin{tabular}{lllll}
\hline & $\begin{array}{l}\text { Garage workers }(\mathbf{n}=\mathbf{3 0}), \\
\text { mean } \pm \text { SD }\end{array}$ & $\begin{array}{l}\text { Control group }(\mathbf{n}=\mathbf{3 0}), \\
\text { mean } \pm \text { SD }\end{array}$ & Change & P-value \\
\hline Systolic blood pressure & $128.67 \pm 18.14$ & $106.33 \pm 9.27$ & $\uparrow 21.01 \%$ & $<0.0001$ \\
Diastolic blood pressure & $90.33 \pm 11.29$ & $75.67 \pm 5.68$ & $\uparrow 19.37 \%$ & $<0.0001$ \\
\hline
\end{tabular}

Table 3 Hematological parameters of garage workers and control group in Harar

\begin{tabular}{|c|c|c|c|c|}
\hline & $\begin{array}{l}\text { Garage workers }(n=30), \\
\text { mean } \pm \text { SD }\end{array}$ & $\begin{array}{l}\text { Control group }(n=30), \\
\text { mean } \pm \text { SD }\end{array}$ & Change & $P$-value \\
\hline WBCs $\left(\times 10^{9} / L\right)$ & $7.9 \pm 1.51$ & $6.72 \pm 2.04$ & $\uparrow 17.56 \%$ & 0.0138 \\
\hline $\operatorname{RBCs}\left(\times 10^{12} / \mathrm{L}\right)$ & $5.13 \pm 0.38$ & $5.46 \pm 0.36$ & $\downarrow 6.04 \%$ & 0.0006 \\
\hline Platelets $\left(\times 10^{9}\right.$ cells $\left./ \mathrm{L}\right)$ & $323.2 \pm 48.82$ & $244.1 \pm 47.3$ & $\uparrow 32.4 \%$ & $<0.0001$ \\
\hline Hemoglobin $(g / d L)$ & $|4.87 \pm 0.7|$ & $15.45 \pm 0.87$ & $\downarrow 3.75 \%$ & 0.0062 \\
\hline Hematocrit (\%) & $43.98 \pm 1.99$ & $46.43 \pm 2.32$ & $\downarrow 5.28 \%$ & $<0.0001$ \\
\hline $\mathrm{MCV}(\mathrm{fL})$ & $83.19 \pm 2.93$ & $85.11 \pm 3.87$ & $\downarrow 2.26 \%$ & 0.0353 \\
\hline $\mathrm{MCH}(\mathrm{pg})$ & $27.99 \pm 1.44$ & $28.33 \pm 1.73$ & $\downarrow 1.2 \%$ & 0.4206 \\
\hline $\mathrm{MCHC}(\%)$ & $32.86 \pm 1.03$ & $33.27 \pm 0.97$ & $\downarrow 1.23 \%$ & 0.1109 \\
\hline
\end{tabular}

Abbreviations: WBCs, white blood cells; RBCs, red $\mathrm{BCs}$; $\mathrm{MCV}$, mean corpuscular volume; $\mathrm{MCH}$, mean corpuscular hemoglobin; $\mathrm{MCHC}$, $\mathrm{MCH}$ concentration.

\section{Regression analysis}

Of the independent variables, working duration was found to be a significant predictor of decreases in hemoglobin, hematocrit, $\mathrm{MCV}$, and $\mathrm{MCHC}$ and a significant predictor of increases WBCs. Increased systolic blood pressure was also predicted by working duration. Smoking was found to be a significant predictors of RBC decrease (Table 4).

\section{Discussion}

Garage workers are exposed to different chemicals in their workplaces. Studies have found that they are exposed to heavy metals like lead, chromium, and cadmium, ${ }^{1,3,26}$ volatile organic compounds (VOCs), such as benzene, ${ }^{27}$ and skinirritating substances, such as oils, greases, solvents, and detergents. ${ }^{6}$ Higher blood levels of lead (4.74 vs $0.74 \mu \mathrm{g} / \mathrm{dL}$ ), cadmium ( $1.17 \mathrm{vs} 0.41 \mu \mathrm{g} / \mathrm{dL}$ ), chromium (5.21 vs $0.98 \mu \mathrm{g}$ / $\mathrm{dL}$ ), zinc (153.56 vs $83.22 \mu \mathrm{g} / \mathrm{dL}$ ), and copper (113.74 vs $85.42 \mu \mathrm{g} / \mathrm{mL}$ ) have been reported among auto-repair garage workers compared with unexposed control subjects. ${ }^{1}$ A study found that garage wastewater was found to be highly contaminated with lead and cadmium, with average concentrations of 4.22 and $1.32 \mathrm{mg} / \mathrm{L}$, respectively. Due to this exposure, garage workers had increased blood lead and cadmium levels compared to the unexposed control group. ${ }^{3}$ Those who work near VOC sources, motor-vehicle exhaust, and gasoline-vapor emissions are also suspected to be exposed to highly elevated VOC levels during their work time. ${ }^{27}$

In Ethiopia, workers' safety and surveillance is a neglected subject. The body concerned does not facilitate heath care. Besides the poor efforts made by the body concerned to ensure the safety of occupational workers, the extent of exposure is worsened by working practices and behavior of the garage workers. Furthermore, the workers are not aware of occupational and environmental health hazards. Lack of protective equipment has been singled out in focus-group discussions as the main observed reason for health problems. ${ }^{28}$ On the other hand, a follow-up study showed that use of personal-protection equipment (PPE) reduced accidents at work. ${ }^{29}$ In the present study, the majority of participants (80\%) were found to be working without any proper PPE. Use of PPE was found to be poor, with only six (20\%) of the garage workers using it, of which three used special shoes (boots), two both gloves and mask, and one a hat. The main reason for not using PPE was found to be lack of provision of the PPE by owner of the garages and discomfort.

Mean RBC count $\left(5.13 \pm 0.38\right.$ vs $5.46 \pm 0.36 \times 10^{12} \mathrm{cells} / \mathrm{L}$, $P<0.001)$, hemoglobin level $(14.89 \pm 0.71$ vs $15.45 \pm 0.87$ $\mathrm{g} / \mathrm{dL}, P<0.01)$, hematocrit level $(43.98 \% \pm 1.99 \%$ vs $46.43 \% \pm 2.32 \%, P<0.0001)$, and $\operatorname{MCV}(83.19 \pm 2.93$ vs $85.11 \pm 3.87 \mathrm{fL}, P<0.05$ ) values of garage workers were significantly lower than those of the control group, while mean WBC $\left(7.9 \pm 1.51\right.$ vs $6.72 \pm 2.04 \times 10^{9}$ cells $\left./ \mathrm{L}, P<0.05\right)$ and platelet ( $323.2 \pm 48.82$ vs $244.1 \pm 47.1 \times 10^{9}$ cells/ $\left.\mathrm{L}, P<0.0001\right)$ counts were significantly higher among garage workers. This difference may be due to exposure of different chemicals in the occupational group. Similar hematological findings have been reported from other studies in which garage workers were exposed to different chemicals. . $, 19,20,26,30^{2}$ 
Table 4 Multiple regression analysis for predictor and outcome variables (blood pressure and hematological parameters) of garage workers in Harar

\begin{tabular}{|c|c|c|c|c|c|c|c|c|}
\hline & \multirow[t]{2}{*}{ Predictors } & \multirow[t]{2}{*}{ Coefficient $(\beta)$} & \multirow[t]{2}{*}{ SE } & \multirow[t]{2}{*}{$P$-value } & \multicolumn{2}{|c|}{$95 \% \mathrm{Cl}$ of $\beta$} & \multirow[t]{2}{*}{$R^{2}$} & \multirow[t]{2}{*}{ F-value } \\
\hline & & & & & Lower & Upper & & \\
\hline \multirow[t]{3}{*}{ RBCs } & Work duration & -0.013 & 0.009 & 0.169 & -0.033 & 0.006 & & \\
\hline & Smoking (yes) & -0.397 & 0.135 & 0.005 & -0.667 & -0.126 & 0.263 & 0.0002 \\
\hline & Constant & 5.411 & 0.053 & & & & & \\
\hline \multirow[t]{4}{*}{ WBCs } & Work duration & 0.079 & 0.044 & 0.075 & 0.008 & 0.168 & & \\
\hline & Drinking (yes) & 0.634 & 0.620 & 0.311 & -0.609 & 1.876 & 0.176 & 0.012 \\
\hline & Chewing khat (yes) & 0.579 & 0.578 & 0.321 & -0.579 & 1.736 & & \\
\hline & Constant & 6.593 & 0.315 & & & & & \\
\hline \multirow[t]{4}{*}{ Hemoglobin } & Work duration & -0.054 & 0.024 & 0.029 & -0.103 & -0.006 & & \\
\hline & Smoking (yes) & -0.519 & 0.297 & 0.086 & -1.115 & 0.075 & 0.234 & 0.002 \\
\hline & Taking shower (yes) & 0.278 & 0.268 & 0.304 & -0.259 & 0.815 & & \\
\hline & Constant & 15.36 & 0.119 & & & & & \\
\hline \multirow[t]{3}{*}{ Hematocrit } & Work duration & -0.181 & 0.06 & 0.004 & -0.302 & -0.061 & 0.264 & 0.0002 \\
\hline & Smoking (yes) & -1.096 & 0.844 & 0.199 & -2.786 & 0.594 & & \\
\hline & Constant & 44.99 & 0.329 & & & & & \\
\hline \multirow[t]{3}{*}{$\mathrm{MCV}$} & Work duration & -0.212 & 0.079 & 0.01 & -0.369 & -0.054 & 0.149 & 0.01 \\
\hline & PPE (nonuser) & 2.324 & 1.428 & 0.109 & -0.536 & 5.184 & & \\
\hline & Constant & 82.741 & 1.383 & & & & & \\
\hline \multirow[t]{3}{*}{$\mathrm{MCH}$} & Work duration & -0.089 & 0.043 & 0.041 & -0.174 & -0.004 & & \\
\hline & Smoking (yes) & -0.106 & 0.597 & 0.859 & -1.303 & 1.089 & 0.103 & 0.045 \\
\hline & Constant & 28.469 & 0.232 & & & & & \\
\hline \multirow[t]{3}{*}{$\mathrm{MCHC}$} & Work duration & -0.069 & 0.025 & 0.007 & -0.119 & -0.019 & & \\
\hline & Smoking (yes) & -0.47 & 0.349 & 0.184 & -1.169 & 0.229 & 0.244 & 0.0004 \\
\hline & Constant & 33.376 & 0.136 & & & & & \\
\hline \multirow[t]{4}{*}{ SBP } & Work duration & 1.761 & 0.398 & $<0.001$ & 0.964 & 2.558 & & \\
\hline & Smoking (yes) & $5.17 \mid$ & 4.888 & 0.295 & -4.621 & 14.964 & 0.562 & $<0.0001$ \\
\hline & Taking shower (yes) & 10.822 & $4.4 I$ & 0.017 & -1.986 & 19.658 & & \\
\hline & Constant & 108.363 & 1.952 & & & & & \\
\hline \multirow[t]{3}{*}{ DBP } & Work duration & 0.917 & 0.224 & $<0.001$ & 0.469 & 1.366 & & \\
\hline & Taking shower (yes) & 10.689 & 2.875 & $<0.001$ & 4.932 & 16.447 & 0.518 & $<0.0001$ \\
\hline & Constant & 87.555 & 1.262 & & & & & \\
\hline
\end{tabular}

Abbreviations: WBCs, white blood cells; RBCs, red blood cells; $\mathrm{MCV}$, mean corpuscular volume; $\mathrm{MCH}$, mean corpuscular hemoglobin; $\mathrm{MCHC}$, $\mathrm{MCH}$ concentration; SBP, systolic blood pressure; DBP, diastolic blood pressure; PPE, personal-protection equipment.

Consistently with our results, decreased erythrocyte ( $4.39 \pm 0.64$ vs $5.2 \pm 0.54 \times 10^{9}$ cells $/ \mathrm{L}, P<0.0001$ ), hemoglobin $(12.97 \pm 2.31$ vs $14.7 \pm 0.74 \mathrm{~g} / \mathrm{dL}, P<0.0001)$, and hematocrit $(38.38 \% \pm 5.49 \%$ vs $43.66 \% \pm 2.03 \%, P<0.0001)$ levels have been reported among car mechanics in Zagazig. ${ }^{6}$ Similarly, the effect of automobile workshops on the health status of automechanics was studied in Pakistan, and significant decreases were observed in hemoglobin $(9.63 \pm 0.24$ vs $11.42 \pm 0.26 \mathrm{~g} / \mathrm{dL}, P<0.05) .{ }^{26}$

Auto-repair workers in Pakistan exposed to aromatic solvents (benzene) showed mean RBCs $(4.75 \pm 0.7$ vs $5.12 \pm 0.4 \times 10^{9}$ cells $\left./ \mathrm{L}, P<0.05\right)$ and hemoglobin $(14.7 \pm 0.6$ vs $15.21 \pm 0.7 \mathrm{~g} / \mathrm{dL}, P<0.05)$ significantly lower than controls, whereas mean $\mathrm{WBC}$ count, $\mathrm{MCV}$, and packed-cell volume were higher among car mechanics compared to controls, though the differences were not statistically significant. ${ }^{19}$ This is in agreement with our study for mean RBC, hemoglobin, and $\mathrm{WBC}$ levels. An association between benzene exposure and lowering of RBC counts has been also reported. ${ }^{31,32}$

In a study conducted in Iran among lead-exposed workers of a car-battery industry, $\mathrm{MCH}$ and $\mathrm{MCHC}$ were negatively correlated with blood lead concentration. However, they failed to detect decreased hemoglobin and hematocrit concentrations in workers. ${ }^{30}$ Similarly, lead exposure among automobile workers showed decreased hemoglobin $(13.14 \pm 1.36$ vs $14.85 \pm 1.46 \mathrm{~g} / \mathrm{dL}, P<0.001)$, hematocrit $(43.65 \% \pm 3.05 \%$ vs $45.5 \% \pm 3.8 \%, P<0.05)$, MCV $(83.1 \pm 4.23$ vs $85.94 \pm 5.29$ fL, $P<0.05)$, MCH (26.63 \pm 1.85 vs $28.23 \pm 2.44 \mathrm{pg}, P<0.01)$, $\mathrm{MCHC}(30.3 \pm 1.44$ vs $32.82 \pm 1.44 \mathrm{~g} / \mathrm{dL}, P<0.001)$, and RBC $\left(5.03 \pm 0.52\right.$ vs $5.89 \pm 0.76 \times 10^{9}$ cells $\left./ \mathrm{L}, P<0.001\right)$ counts and increased total WBC counts $\left(7.5 \pm 1.39\right.$ vs $6.73 \pm 1.82 \times 10^{9}$ cells $/ \mathrm{L}, P<0.05)$ compared to controls. It was indicated that the absorption of lead is higher in automobile workers and affects heme biosynthesis and hematological parameters. ${ }^{20}$ 
In this study, mean platelet value was increased among garage workers compared to the control group. However, this result is contrary to previous studies, ${ }^{33,34}$ which showed a negative association of such exposure with platelets, along with other parameters. Significantly increased total WBC counts in these automobile workers could be due to more exposure to dust or fumes of toxic chemicals. This WBC increase may also be due to certain inflammatory and infectious conditions, because an essential function of WBCs is to provide primary defense. ${ }^{19}$

Significantly decreased hemoglobin, MCV, and RBC counts in automobile workers identified by this study might be due to decreased heme concentration, iron absorption, or maturation of RBCs by different toxic chemicals. Different chemical exposure times affect the hematopoietic system and result in altered hematological parameters. For example, lead impairs the rate of incorporation of iron into mature and immature RBCs in cases of human lead poisoning. ${ }^{20}$ Benzene is well known for its hematological and leukemogenic properties, as prolonged benzene exposure can induce bone-marrow toxicity, which is expressed in decreased BC counts. ${ }^{35}$

Several studies have reported increases in blood pressure among workers exposed to lead concentrations. Occupational exposure to higher ambient lead is related to increased systolic and diastolic blood pressures. Blood lead values correlated significantly with systolic and diastolic blood pressures..$^{36}$ A general population exposed to very low lead levels showed increased blood lead was associated with small increases in blood pressure. ${ }^{37}$ It has been described that significant blood pressure rises with increased blood lead concentrations in 36 male subjects with an occupational exposure to lead of $39.5 \mu \mathrm{g} / \mathrm{dL} .{ }^{38}$ A cross-sectional study of male workers exposed to lead examined the association between environmental lead and blood pressure, and showed that systolic blood pressure rose with increasing blood lead from $127 \mathrm{mmHg}$ in subjects with blood lead $<21 \mu \mathrm{g} / \mathrm{dL}$ to $133 \mathrm{mmHg}$ in those with blood lead $>50 \mu \mathrm{g} / \mathrm{dL} .{ }^{39}$

Increased systolic blood pressure $(128.67 \pm 18.14$ vs $106.33 \pm 9.27 \mathrm{mmHg}, P<0.0001)$ and diastolic blood pressure $(90.33 \pm 11.29$ vs $75.67 \pm 5.68 \mathrm{mmHg}, P<0.0001)$ in garage workers compared to controls in this study indicate that occupational chemical exposure alters blood pressure. Among different chemicals, it is reported that blood lead levels contribute independently to increased systolic and diastolic blood pressures. ${ }^{20}$ Significantly high rates of hypertension were reported in the group with high exposure to benzene compared to the group with less exposure. A possible mechanism of benzene-induced hypertension could be disturbance of the nitric oxide process, subsequently leading to hypertension. ${ }^{40}$ Similarly, a significant association was observed between hypertension and exposure to a mixture of organic solvents in a study conducted in Iran among carmanufacturing workers. Significantly higher mean elevation values of $7 \mathrm{mmHg}$ in systolic blood pressure and $6.9 \mathrm{mmHg}$ in diastolic blood pressure among workers exposed to mixture of organic solvents compared to the control group were observed..$^{21}$ From this, it can be concluded that increased blood pressure is prominent in garage workers known to be chronically exposed to different chemicals.

In the present study, regression analyses showed that smoking was a significant predictor of decrease in RBCs. A similar finding was obtained from a study conducted in Pakistan, where smokers showed decreased mean RBC and hemoglobin counts compared to nonsmokers. ${ }^{19}$ Smoking has been found to be an important factor in direct exposure to different chemicals, such as benzene ${ }^{41}$ and other aromatic VOCs. ${ }^{27}$ In addition to smoking having a direct effect on the hematopoietic system, it enhances effects of exposure to different chemicals.

In the present study, working duration was also found to be an important predictor of most hematological parameters. Declines in hemoglobin, hematocrit, $\mathrm{MCH}$, and $\mathrm{MCHC}$ were predicted by work duration. These findings are in agreement with those of studies conducted in Pakistan, where garage workers with longer exposure experienced more adverse effects on hematological parameters (mainly RBCs and hemoglobin). ${ }^{19}$ It has been reported that hematotoxicity, genotoxicity, and acute myelogenous leukemia are enhanced by long exposure. ${ }^{42}$ Several studies have shown positive correlations between blood levels of chemical contaminants with duration of exposure ${ }^{43,44}$ All of these studies show that health risk is directly associated with prolonged toxin exposure. This is explained by the fact that the longer duration of work, the higher the level of exposure to different affecting agents.

This study has some limitations. We evaluated the picture of blood pressure and hematological parameters in garage workers exposed to a mixture of different chemicals. We did not measure the specific chemicals to which the garage workers were exposed nor did we define the effects of a single chemical. It would be better to assess types of occupational chemical exposure and their effect on health in future studies. Furthermore, there were no records for baseline and periodic examination of blood pressure or hematological parameters of garage workers to identify changes that could be attributed to occupational chemical exposure. 


\section{Conclusion}

The majority of the workers were unaware of the hazardous effects of chemicals and did not use any kind of personal protective equipment during their work in the station. To minimize chemical exposure at workplaces, placement of proper preventive and control measures need to be taken by the concerned body. Specifically, the local health bureau and different concerned health professionals should develop and enforce strict regulations, instructions, and guidelines for occupational health and safety to protect workers.

The findings regarding blood pressure and hematological parameters showed there were decreased mean RBC counts, hemoglobin levels, hematocrit levels, and MCV and increased mean WBC counts, platelet counts, systolic blood pressure, and diastolic blood pressure among the garage workers compared to the control group. Therefore, regular screening and monitoring of garage workers is important to reduce the long-term adverse effects of occupational chemical exposure. Furthermore, long-term prospective studies of garage workers would help to gain a more comprehensive picture of long-term effects of chemical exposure and identify the specific types of chemicals to which the workers are exposed.

\section{Acknowledgments}

The authors gratefully acknowledge Haramaya University for funding this research. Our special thanks go to our study participants (garage workers and teachers and students of the College of Health and Medical Sciences, Haramaya University) for agreeing to participate in this study. We would also like to express our sincere thanks to the data collectors for their management, collection, and analysis of blood specimens.

\section{Author contributions}

ZA designed the study, participated in data collection, analysis, and drafted the manuscript. FU and AG participated in study design, analysis, write-up, and critically revised the manuscript. All authors gave final approval of the version to be published, and agree to be accountable for all aspects of the work.

\section{Disclosure}

The authors report no conflicts of interest in this work.

\section{References}

1. Ishola AB, Okechukwu IM, Ashimedua UG, et al. Serum level of lead, zinc, cadmium, copper and chromium among occupationally exposed automotive workers in Benin city. Int J Environ Pollut Res. 2017;5(1):70-79.

2. Dant T, Bowles D. Dealing with dirt: servicing and repairing cars. Sociol Res Online. 2003;8(2):1-31.
3. Basu R, Biswas A, Biswas K, et al. An attempt to search the health status of garage workers: a neglected part in India. Int $J$ Adv Res. 2015;3(7):1466-1471.

4. Loewenson RH. Health impact of occupational risks in the informal sector in Zimbabwe. Int J Occup Environ Health. 1998;4(4):264-274.

5. Schwartz E. Proportionate mortality ratio analysis of automobile mechanics and gasoline service station workers in New Hampshire. Am J Ind Med. 1987;12(1):91-99.

6. El-Saadawy MS, Attwa EM, El-Tayeb IM, Zalat MM. Dermatoses and hematological disorders among car mechanics in Zagazig city and their effects on quality of life. Zagazig Univ Med J. 2011;17(2):142-156.

7. Ahmed K, Ayana G, Engidawork E. Lead exposure study among workers in lead acid battery repair units of transport service enterprises, Addis Ababa, Ethiopia: a cross-sectional study. J Occup Med Toxicol. 2008;3:30.

8. Tchounwou PB, Yedjou CG, Patlolla AK, Sutton DJ. Heavy metal toxicity and the environment. EXS. 2012;101:133-164.

9. World Health Organization. Biological monitoring of chemical exposure in the workplace: guidelines. 1996. Available from: http://apps.who.int/ iris/bitstream/10665/41856/1/WHO_HPR_OCH_96.1.pdf. Accessed February 8, 2018.

10. Fiserova-Bergerova V, Mraz J. Biological monitoring of exposure to industrial chemicals. 2001. Available from: http://onlinelibrary.wiley. com/doi/10.1002/0471435139.hyg042/abstract;jsessionid=3966A878 C3156216E89894F034383E3E.f03t04. Accessed February 8, 2018.

11. Paustenbach D, Galbraith D. Biomonitoring and biomarkers: exposure assessment will never be the same. Environ Health Perspect. 2006;114(8):1143-1149.

12. Au WW. Usefulness of biomarkers in population studies: from exposure to susceptibility and to prediction of cancer. Int J Hyg Environ Health. 2007;210(3):239-246.

13. American Conference of Governmental Industrial Hygienists. Threshold Limit Values for Chemical Substances and Physical Agents and Biological Exposure Indices. Cincinnati: ACGIH; 1995.

14. German Research Foundation. Maximum Concentrations at the Workplace and Biological Tolerance Values for Working Materials 1984. Weinheim, Germany: Wiley-VCH; 1984.

15. Gomes J, Lloyd O, Norman N, Pahwa P. Dust exposure and impairment of lung function at a small iron foundry in a rapidly developing country. Occup Environ Med. 2001;58(10):656-662.

16. Pala K, Turkkan A, Gucer S, Osman E, Aytekin H. Occupational lead exposure: blood lead levels of apprentices in Bursa, Turkey. Ind Health. 2009;47(1):97-102.

17. Dongre NN, Suryakar A, Patil AJ, Rathi D. Occupational lead exposure in automobile workers in north Karnataka (India): effect on liver and kidney functions. Al Ameen J Med Sci. 2010;3(4):284-292.

18. Kang SK, Lee MY, Kim TK, Lee JO, Ahn YS. Occupational exposure to benzene in South Korea. Chem Biol Interact. 2005;153-154:65-74.

19. Kamal A, Malik RN. Hematological evidence of occupational exposure to chemicals and other factors among auto-repair workers in Rawalpindi, Pakistan. Osong Public Health Res Perspec. 2012;3(4):229-238.

20. Dongre NN, Suryakar AN, Patil AJ, Ambekar JG, Rathi DB. Biochemical effects of lead exposure on systolic and diastolic blood pressure, heme biosynthesis and hematological parameters in automobile workers of north Karnataka (India). Indian J Clin Biochem. 2011;26(4):400-406.

21. Attarchi M, Golabadi M, Labbafinejad Y, Mohammadi S. Combined effects of exposure to occupational noise and mixed organic solvents on blood pressure in car manufacturing company workers. Am J Ind Med. 2013;56(2):243-251.

22. Udonwa NE, Uko EK, Ikpeme BM, Ibanga IA, Okon BO. Exposure of petrol station attendants and auto mechanics to premium motor sprit fumes in Calabar, Nigeria. J Environ Sci Pub Health. 2009;2009:281876.

23. Obianime AW, Odili O, Olorunfemi OJ, Wokoma TO, Chuemere AN. Toxic air and soil in automobile workshop impact negatively on the health status of automechanics: the Nigeria environment. Int J Pharm Pharmacol. 2017;1(3):111. 
24. Adela Y, Ambelu A, Tessema DA. Occupational lead exposure among automotive garage workers: a case study for Jimma town, Ethiopia. J Occup Med Toxicol. 2012;7(1):15.

25. Arkin CF, Bessman J, Calam R, et al. Procedures for the Collection of Diagnostic Blood Specimens by Venipuncture: Approved Standard. 5th ed. Wayne, PA: National Committee for Clinical Laboratory Standards; 2003.

26. Khan AA, Inam S, Idrees M, Dad A, Gul K, Akbar H. Effect of automobile workshop on the health status of automechanics in NWFP, Pakistan. Afr J Environ Sci Technol. 2010;4(4):192-200.

27. Jo WK, Song KB. Exposure to volatile organic compounds for individuals with occupations associated with potential exposure to motor vehicle exhaust and/or gasoline vapor emissions. Sci Total Environ. 2001;269(1):25-37.

28. Rongo L, Barten F, Msamanga G, Heederik D, Dolmans W. Occupational exposure and health problems in small-scale industry workers in Dar es Salaam, Tanzania: a situation analysis. Occup Med. 2004;54(1): 42-46.

29. Bull N, Riise T, Moen B. Work-related injuries and occupational health and safety factors in smaller enterprises: a prospective study. Occup Med. 2002;52(2):70-74.

30. Kianoush S, Balali-Mood M, Mousavi SR, et al. Clinical, toxicological, biochemical, and hematologic parameters in lead exposed workers of a car battery industry. Iranian J Med Sci. 2013;38(1):30-37.

31. Qu Q, Shore R, Li G, et al. Hematological changes among Chinese workers with a broad range of benzene exposures. Am J Ind Med. 2002;42(4):275-285.

32. Cody RP, Strawderman WW, Kipen HM. Hematologic effects of benzene: job-specific trends during the first year of employment among a cohort of benzene-exposed rubber workers. J Occup Environ Med. 1993;35(8):776-782.
33. Khuder SA, Youngdale MC, Bisesi MS, Schaub EA. Assessment of complete blood count variations among workers exposed to low levels of benzene. J Occup Environ Med. 1999;41(9):821-826.

34. Rothman N, Li GL, Dosemeci M, et al. Hematotoxocity among Chinese workers heavily exposed to benzene. Am J Ind Med. 1996;29(3):236-246.

35. Javelaud B, Vian L, Molle R, et al. Benzene exposure in car mechanics and road tanker drivers. Int Arch Occup Environ Health. 1998;71(4):277-283.

36. Rapisarda V, Ledda C, Ferrante M, et al. Blood pressure and occupational exposure to noise and lead $(\mathrm{Pb})$ : a cross-sectional study. Toxicol Ind Health. 2016;32(10):1729-1736.

37. Vaziri ND. Mechanisms of lead-induced hypertension and cardiovascular disease. Am J Physiol Heart Circ Physiol. 2008;295(2):H454-H465.

38. Schuhmacher M, Bosque M, Domingo J, Corbella J. Effects of chronic lead and cadmium exposure on blood pressure in occupationally exposed workers. Biol Trace Elem Res. 1994;41(3):269-278.

39. Maheswaran R, Gill JS, Beevers DG. Blood pressure and industrial lead exposure. Am J Epidemiol. 1993;137(6):645-653.

40. Wiwanitkit V. Benzene exposure and hypertension: an observation. Cardiovasc J Afr. 2007;18(4):264-265.

41. Brugnone F, Perbellini L, Romeo L, Cerpelloni M, Bianchin M, Tonello A. Benzene in blood as a biomarker of low level occupational exposure. Sci Total Environ. 1999;235(1):247-252.

42. Chen Y, Li G, Yin S. [Individual susceptibility to hematotoxicity from benzene exposure and the genetic polymorphism of metabolic enzymes]. Wei Sheng Yan Jiu. 2002;31(2):130-132. Chinese.

43. Kirkeleit J, Riise T, Bråtveit M, Pekari K, Mikkola J, Moen BE. Biological monitoring of benzene exposure during maintenance work in crude oil cargo tanks. Chem Biol Interact. 2006;164(1):60-67.

44. Foo SC. Benzene pollution from gasoline usage. Sci Total Environ. 1991;103(1):19-26.
Risk Management and Healthcare Policy

\section{Publish your work in this journal}

Risk Management and Healthcare Policy is an international, peer-reviewed, open access journal focusing on all aspects of public health, policy, and preventative measures to promote good health and improve morbidity and mortality in the population. The journal welcomes submitted papers covering original research, basic science, clinical and epidemiological

\section{Dovepress}

studies, reviews and evaluations, guidelines, expert opinion and commentary, case reports and extended reports. The manuscript management system is completely online and includes a very quick and fair peerreview system, which is all easy to use. Visit http://www.dovepress.com testimonials.php to read real quotes from published authors. 